Arch. Vet. Scienc. 3(1):45-49, 1998

Printed in Brazil

\title{
DENTAL GERM FORMATION AS INFLUENCED BY 5-FLUOROURACIL (5-FU) IN NEWBORN RATS
}

\author{
ROSILENE FERNANDES DA ROCHA ${ }^{1}$; WILMA P. BASTOS-RAMOS ${ }^{2}$; \\ THALES ROCHA MATTOS FILHO ${ }^{2}$; TEREZINHA O. NOGUEIRA ${ }^{3}$
}

${ }^{1}$ Departamento de Patologia. ${ }^{2}$ Departamento de Ciências Básicas - Faculdade de Odontologia - UNESP 12.245-000 -S. José dos Campos - SP. ${ }^{3}$ Departamento de Anestesiologia e Terapêutica Medicamentosa Faculdade de Odontologia - UNICAMP -13414-000 - Piracicaba - SP

\begin{abstract}
It was studied the influence of the antimitotic drug 5 - fluorouracil (5-FU), administered to pregnant rats, on dental germ formation of newborn rats. A total of 125 female aged 90-100 days and 15 male adult rats (Rattus rattus norvaegicus, albinus, Wistar) were used. The drug was injected intraperitoneally in single doses to females at the $9^{\text {th }}, 10^{\text {th }}, 11^{\text {th }}, 12^{\text {th }}$ and $13^{\text {th }}$ days of pregnancy. The animals were divided in four groups according to the doses administered: 10, 20, 30 and $40 \mathrm{mg} / \mathrm{kg}$. Results show that the drug induced no toxicity to mothers, other than loss of body weight with higher doses $(30-40 \mathrm{mg} / \mathrm{kg})$, but caused in the fetuses dental germ anomalies and body external malformations. The proportion of such anomalies were, besides dose dependent, influenced by the day of pregnancy when the drug was administered to the mothers: there was a greater sensitivity at the $9^{\text {th }}$ day and a lesser one at the $10^{\text {th }}$ day. Higher doses $(30-40 \mathrm{mg} / \mathrm{kg})$ caused frequently embryonic death or fetal uterine reabsorption. Agenesia of the dental germ was frequently found.
\end{abstract}

Key Words: antimitotic drugs; 5-fluorouracil; dental germ; fetal malformation.

RESUMO - Foi estudada a influência da droga antimitótica 5-fluoruracil (5-FU), administrada a ratas prenhes sobre a formação do germe dental de ratos recém nascidos. Foram utilizadas 125 fêmeas com 90-100 dias de idade e 15 machos adultos (Rattus rattus norvaegicus, albinus, Wistar). A droga foi injetada por via intraperitoneal a ratas grávidas, em doses únicas, aos $9^{\circ}, 10^{\circ}, 11^{\circ}, 12^{\circ}$ ou $13^{\circ}$ dias de gestação. Os animais foram divididos em quatro subgrupos de acordo com a dose administrada: 10, 20, 30 e $40 \mathrm{mg} / \mathrm{kg}$. Os resultados mostraram que nessas doses, o 5-FU não teve efeito tóxico nas ratas prenhes, alem de perda de peso com doses mais elevadas (30-40 mg/kg), enquanto causou anomalias dentais nos embriões, bem como malformações externas. A proporção de tais anomalias foi, alem de dose dependente, influenciada pelo dia de gestação no qual antimitótico foi administrado às mães: foi observada maior sensibilidade ao $9^{\circ}$ dia e menor ao $10^{\circ}$ dia. Doses mais elevadas $(30-40 \mathrm{mg} / \mathrm{kg})$ causaram freqüentemente morte do embrião e reabsorção fetal. Agenesia do germe dentário foi freqüentemente observada.

Palavras-Chave: drogas antimitóticas; 5-fluorouracil; germe dentário; malformações fetais.

\section{Introduction}

Antimitotic drugs are useful for the treatment of cancer due to its toxic action to highly proliferating tumor cells. The limitation of its use is that they are also toxic to cells of normal tissues in the mitotic phase, so that the proliferating normal tissue is sensitive to these drugs in proportion to its mitotic activity, what means severe unwanted side effects. Many observations have been made in drug treated cancerous pregnant women and in experimental animals given antimitotic drugs. Results show not predictable unwanted effects on embryos or newborn. It was reported in pregnant women (STADLER and KNOWLES, 1971; BLATT et al., 1980; STEPHENS et al., 1980; TOBIAS and BLOOM, 1980; GILILLAND and WEINSTEIN, 1983;) that some chemotherapic drugs such as adriamycin, actinomycin D and vincristin, administered before and within the first 3 months of pregnancy caused no problems to the newborn.
However, the authors refer to fetal malformations due to alkylating (cyclophosphamide, bussulfan and chlorambucil) and antimetabolic agents (aminopterin, thioguanine and 5-fluorouracil) given to women during the 3 first months of pregnancy. STEPHENS et al. (1980) refer to abortion of an abnormal fetus, from a mother given 5-fluorouracil during the $11^{\text {st }}-12^{\text {nd }}$ weeks of pregnancy. Experimental studies in rodents, rabbits and monkeys have shown embryotoxic and teratological effects of antimitotic drugs. Studies have been carried out with 5-fluorouracil (DAGG, 1960; WILSON, 1971; SHAH and MACKAY, 1978; GRAFTON et al., 1987), adriamicyn and daunomicyn (THOMPSON et al., 1976), 3,3dimethyl-1-phenyltriazene (FRANK et al., 1989). For further pharmacological references on antimitotic drugs, see CHABNER et al., (1996). The influence of anticancer drugs on dental development has been widely studied. The rat has a special experimental interest due to the 
continuous growth of incisive teeth, lasting for the whole life of the animal. At any time, one can observe, in each tooth, the whole cycle of the organ development: growth, calcification and eruption (FARRIS and GRIFFITH, 1971; NISHMURA and TANIMURA, 1976; DAHL and KOPPANG, 1985). Dental anomalies in rats and mice related to disturbance of dental growth and tissular alterations were observed with antimitotic drugs: cyclophosphamide (NORDLINDER, 1971; KOPPANG, 1973, 1978; MASSINI, 1975; VAHLSING, 1975, 1977; MATHEUS and HETEM, 1990; MATHEUS et al., 1994) colchicine (DIAS COSTA, 1978; NOGUEIRA et al., 1980, 1981), doxorubicin (DAHL and KOPPANG, 1985), 5-fluorouracil (DE DEUS and HAN, 1976). BASTOS-RAMOS et al., (1992) showed that in adult rats 5-fluorouracil did not disturb dental growth, unless when very high near to lethal doses were used. The present research intends to study the influence of the very potent anticancer drug 5fluorouracil, given to mothers in early phases of pregnancy, in increasing doses, on the dental germ of their offsprings as well its embryotoxic and general teratogenic effects.

\section{Material and Methods}

A total of 140 adult rats (Rattus rattus norvaegicus, albinus, Wistar), in good controlled health conditions were used. 125 were virgin females, aged 90-100 days and 15 were adult male rats. Males and females were put together and the fertilized females were used for the experiment. They were divided in four groups, according to the doses of 5-flourouracil administered. A control group injected with saline was run in parallel. The drug was administered intraperitoneally, in single doses, at the $9^{\text {th }}, 10^{\text {th }}, 11^{\text {th }}, 12^{\text {th }}$ and $13^{\text {th }}$ days of pregnancy. Four doses of 5-fluorouracil were used, as follows: $10 \mathrm{mg} / \mathrm{kg} ; 20 \mathrm{mg} / \mathrm{kg}: 30 \mathrm{mg} / \mathrm{kg}$ and 40 $\mathrm{mg} / \mathrm{kg}$. At the $21^{\text {st }}$ day of pregnancy, the rats were anesthetized with ethyl ether, the uterus exposed by laparoscopy, the embryos were taken out for the observation of an earlier fetuses reabsorption. The newborn rats were weighed and observed under lens (4 x magnification) regarding their external characteristics, to check possible malformations. For microscopic studies, the heads were cut off, fixed in $10 \%$ formol solution for $24 \mathrm{~h}$, cut at medial sagital plane, hydrated, dehydrated, diaphanized and prepared in paraffin to histology. The tissues were examined by light microscopy. In every group, control experiments with saline treated rats were run.

For statistical analysis of the results, Tuckey test, variance analysis and $\mathrm{X} 2$ test were used.

\section{Results}

1. Toxicity of 5-fluorouracil to the pregnant rats. No important sign of intoxication was observed in 5-FU treated mothers, but a poor gain or even loss of body weight in the ones injected with higher doses $(30-40 \mathrm{mg} / \mathrm{kg})$. In these animals, a decrease of $30 \%$ of successful pregnancy, as compared to controls (100\%), was observed. However, when these doses were given at the $13^{\text {th }}$ day fertilization, the pregnancy was less affected. It was not affected at all with doses of 10 or $20 \mathrm{mg} / \mathrm{kg}$ injected in any time of pregnancy. 2 . Toxicity of 5-FU to fetal uterine implantation. The number of uterine embryonic implantation was significantly reduced when the drug was injected at the $9^{\text {th }}$ day of pregnancy, and it was expressive with doses of 30 and $40 \mathrm{mg} / \mathrm{kg}$. By the time of birth $100 \%$ of the offspring from control not treated mothers were alive. 3. Fetal dental germ abnormalities. The abnormalities detected at birth were of different kind, as follows: absence of dental germ; hyperchromatic and roundish nucleus pulp cells; inflammatory processes; reduced bone tissue; cleft at the edging of the germ. The proportion of abnormalities increased with the doses of 5-FU given to mothers and were related to the period of pregnancy it was given. With higher doses (30 40 $\mathrm{mg} / \mathrm{kg}$ ) it was poorly observed due to frequent uterine reabsorption. No abnormality was found in offspring from control mothers. Results are summarized in Table 1. 4. Fetal gross abnormalities. Somatic general abnormalities were observed in newborn from 5-FU treated mothers, most of which showed also dental germ problems. The abnormalities were: labial cleft; cephalic extrusion; cephalic hemorrhage; total or partial absence of limbs, fingers or tail; diffuse edema. The malformations increased with doses of 5-FU and was related to the day of pregnancy the drug was administered to the mothers. Results are summarized in Table 1. 
Dental Germ Formation as Influenced by 5-Fluorouracil (5-FU) in Newborn Rats

Table 1. Influence of 5-fluorouracil (5-FU), administered to pregnant mothers, on offspring rats: gross somatic malformations* and dental abnormalities**.

\begin{tabular}{|c|c|c|c|}
\hline $\begin{array}{c}\text { Time of pregnancy } \\
\text { (days) }\end{array}$ & $\begin{array}{l}\text { Dose of 5-FU } \\
(\mathrm{mg} / \mathrm{kg})\end{array}$ & $\begin{array}{c}\text { Somatic malformation } \\
\text { (\% of animals) }\end{array}$ & $\begin{array}{c}\text { Dental abnormalites } \\
\text { (\% of animals) }\end{array}$ \\
\hline \multirow[t]{4}{*}{$9^{0}$} & 10 & $21 \%$ malformations & $15 \%$ abnormalities \\
\hline & 20 & $20 \%$ malformations & $19 \%$ abnormalities \\
\hline & 30 & $100 \%$ fetal reabsorption & ------ \\
\hline & 40 & $100 \%$ fetal reabsorption & ------ \\
\hline \multirow[t]{4}{*}{$10^{0}$} & 10 & Normal & Normal \\
\hline & 20 & Normal & Normal \\
\hline & 30 & Normal & Normal \\
\hline & 40 & Normal & Normal \\
\hline \multirow[t]{4}{*}{$11^{0}$} & 10 & Normal & Normal \\
\hline & 20 & Normal & Normal \\
\hline & 30 & $100 \%$ fetal reabsorption & ------ \\
\hline & 40 & $100 \%$ fetal reabsorption & ------ \\
\hline \multirow[t]{4}{*}{$12^{0}$} & 10 & Normal & Normal \\
\hline & 20 & $22 \%$ malformations & $20 \%$ agenesia \\
\hline & 30 & $47 \%$ malformations & $21 \%$ agenesia \\
\hline & 40 & $97 \%$ reabsorption $/ 1$ dead & ----- \\
\hline \multirow[t]{4}{*}{$13^{0}$} & 10 & Normal & Normal \\
\hline & 20 & Normal & Normal \\
\hline & 30 & $72 \%$ malformations & $20 \%$ agenesia \\
\hline & 40 & $\begin{array}{l}37 \% \text { fetal reabsorption } \\
\text { and } 63 \% \text { dead fetuses }\end{array}$ & ----- \\
\hline
\end{tabular}

* Gross somatic malformations: labial cleft; encephalic extrusion; encephalic hemorrhage; total or partial absence of limbs, finger or tail; diffuse edema. **Dental abnormalities: absence of dental germ; hyperchromatic and roundish pulp cells; inflammatory processes; reduced bone tissue; cleft at the edge of the germ.

\section{Discussion}

It is well known that many drugs administered in pregnancy, mainly during the early stages, in human or animals, can be damaging to the embryo or fetus, inducing premature death and absortion or uterine reabsorption. Otherwise, they can cause death at birth, or the newborn survives with morphological or functional abnormalities. Regarding to this, antimitotic drugs, widely used in the control of cancer, are particularly important, due to their high toxicity to growing tissues, being a real problem if it has to be given to cancerous mother. Why to study the embryonic responses to a powerful anticancer drug like 5-fluorouracil, if it is clearly expected to be damaging to such organisms? It is important because the experimental results in animals, using this and other anticancer drugs, as well as clinical observations in cancerous pregnant women given antimitotics have shown that there are dissimilar responses, according to the drug, the doses and the period of pregnancy (STADLER and KNOWLES, 1971; TOBIAS e BLOOM, 1980; GILILLAND and WEINSTEIN, 1983; BLATT et al., 1992). As far as to dental growth is concerned, previous experiments in our laboratories (BASTOS-RAMOS et al., 1992) have shown that 5-fluorouracil exerts a reduced influence on the dental development of adult rats, causing some impairment only when very high doses, near to lethal were given. These results allow to suppose that dental growing tissues in rats are somewhat resistant to the antimitotic action of this drug. These findings induced to study its influence 
on embryo's dental germ formation, when given to pregnant mothers, as compared to other embryotoxic or teratogenic effects in the same animal. The initial dose chosen for the experiments - $40 \mathrm{mg} / \mathrm{kg}$, resulted to be very embryotoxic, giving rise to many dead embryos or very high rates of uterine embryonic reabsorption. The mothers showed no important signs of intoxication, other than loss of weight with higher doses or poor weight gain, which could be related to failing in pregnancy in most of them. Using lower doses-20 and $10 \mathrm{mg} / \mathrm{kg}$, no signs of toxicity to mothers were observed but they were appropriated to cause embryonic malformations. One can establish some parallel between the percentage of body malformations and dental anomalies when 10 and $20 \mathrm{mg} / \mathrm{kg}$ of $5-\mathrm{FU}$ were used. However, with doses of $30 \mathrm{mg} / \mathrm{kg}$, dental germ anomalies were half to one third less frequent as compared to the proportion of general body malformations, considering the number of fetuses examined. Very important to the results, other than the doses used, were the days of pregnancy in which 5-FU was injected. It was chosen the period from the $9^{\text {th }}$ to the $13^{\text {th }}$ days of pregnancy, as long as it is the most important period to embryonic formation of structures of the rat head. DAGG (1960) refers that the $9^{\text {th }}$ day is very important for the formation of ocular structures. Our results can be considered concordant with this Author's finding. As a matter of fact, when given at the $9^{\text {th }}$ day, the occurrence of malformations was more frequent with doses of 10 and $20 \mathrm{mg} / \mathrm{kg}$ and carried out total absorption of embryos with doses of 30 and $40 \mathrm{mg} / \mathrm{kg}$. The high rate of fetal reabsorption is consistent with findings of SHAH and MACKAY (1978) using hamsters and 5-fluorouracil. In our experiments the sensitivity was less evident when the drug was administered at the $10^{\text {th }}$ and $11^{\text {th }}$ days: no malformations were observed with doses of 10 and $20 \mathrm{mg} / \mathrm{kg}$ although there was no birth with doses of 30 an $40 \mathrm{mg} / \mathrm{kg}$ administered at the $11^{\text {th }}$ day if pregnancy. On the other hand, a high rate of malformations were observed with 5-FU injected at the 12th day of pregnancy, that is $22 \%$ with 20 $\mathrm{mg} / \mathrm{kg}$ and $47 \%$ with $30 \mathrm{mg} / \mathrm{kg}$. The $12^{\text {th }}$ day is just the crucial day for the closing of the palate, what could be related to our results. The least sensitivity was observed when $5-\mathrm{Fu}$ was given at the $10^{\text {th }}$ day (100\% normal), and at the $13^{\text {th }}$ day of pregnancy: with doses of 10 and $20 \mathrm{mg} / \mathrm{kg}$, all fetuses were normal; with doses of $30 \mathrm{mg} / \mathrm{kg}, 20 \%$ of the fetuses had agenesia of dental germ and $72 \%$, body malformations. At this time, doses of $40 \mathrm{mg} / \mathrm{kg}$, usually leading to total uterine embryo reabsorption, gave rise to dead but completely formed fetuses. The results of this work are poorly explained by the current knowledge about rat embryology, but are expressive to lead further experiments, to clear the influence of doses of 10 and $20 \mathrm{mg} / \mathrm{kg}$, given to mothers at the $9^{\text {th }}$ day of pregnancy, on the development of dental tissues, from birth to adult age.

\section{Acknowledgements}

The Authors are grateful to Prof. Gisele S. Macedo for linguistic revision and to Biologist Mônica Guimarães for technical assistance.

\section{REFERENCES}

BASTOS-RAMOS, W.P.; COELHO, M.J.P.; NOGUEIRA, T.O.; AMORIM, J.B. Drogas antimitóticas e desenvolvimento de incisivos inferiores de ratos: estudos com o fluorouracil. Rev. Odontol. UNESP. 21:11-24, 1992.

BLATT, J.; MULVIHILL, J.J.; ZIEGLER, J.L. Pregnancy outcome following cancer chemotherapy. Am. J. Med. 69: 828-32, 1980.

CHABNER, B.A.; ALLEGRA, C.J.; CURT, G.A.; CALABRESI, P. Antineoplasic agents. In: GOODMAN \& GILMAN'S The Pharmacological Basis of Therapeutics. New York: McGraw-Hill, 1996. p. 1233-87.

DAGG, C.P. Sensitive stages for the production of developmental abnormalities in mice with 5fluoruracil. Am. J. Anat. 106: 89-96, 1960.

DAHL, J.E.; KOPPANG, N.S. Renewal and migration of rat incisor mesenchymal cells after doxorubicin administration. Acta Odontol. Scand. 43:97-103, 1985.

DE DEUS, Q.D.; HAN, S.S. Modificações ultraestruturais de fibroblastos da polpa dental após administração de 5-fluoruracil. Arq. Cent. Est. Cur. Odont. 13:149-75, 1976.

DIAS COSTA, A.M. Estudos com a colchicina no crescimento de dentes de ratos. Piracicaba, 1978. Dissertação de Mestrado - Faculdade de Odontologia de Piracicaba, Universidade Estadual de Campinas (UNICAMP).

FARRIS. E.J.; GRIFFITH, Jr. J.Q. The rat in laboratory investigation. $2^{\text {nd }}$ ed., New York: Hafner, 1971. 542p.

FRANK, A.A.; THOMPSON, D.J.; KAZACOS, E.A. Teratogenicity of 3,3-Dimethyl-1-phenyltriazene in the rat: gross malformations including micrognathism. Teratology. 39:53-61, 1989.

GILILLAND, J.; WEINSTEIN, L. The effects of cancer chemotherapeutic agents on the developing fetus. Obstr. Gynecol. Surv. 38:6-13, 1983.

GRAFTON, T.T.; BAZARE Jr.J.J.; HANSEN, D.K. The in vitro embriotoxicity of 5-fluoruracil in rat embryos. Teratology. 36:371-77, 1987.

KOPPANG, H.S. Histomorphologic investigations on the effect of cyclophosphamide on dentinogenesis of the rat incisor. Scand. J.Dent.Res. 81:383-96, 1973.

KOPPANG, H.S. Histomorphologic investigations of dentinogenesis in incisors of offspring of cyclophosphamide-treated pregnant rats. Scand. J. Dent. Res. 86:444-58, 1978. 
MASSINI, N. Estudo do crescimento dentário em ratos tratados com ciclofosfamida (Enduxan). Piracicaba, 1975. Dissertação (Mestrado em Ciências Biológicas)- Faculdade de Odontologia de Piracicaba, Universidade Estadual de Campinas (UNICAMP).

MATHEUS, M.T.G.; HETEM, S. Efeito da ciclofosfamida sobre o desenvolvimento do germe dental do incisivo do camundongo. Rev. Odontol. UNESP. 19:41-9, 1990.

MATHEUS, M.T.G.; HETEM, S.; GUIMARÃES NETO; SILVEIRA, Z.V. Efeitos da ação da ciclofosfamida administrada durante a prenhez no desenvolvimento de molares de fetos de camundongos. Rev. Odontol. UNESP. 23:9-20, 1994.

NISHIMURA, H.; TANIMURA, T. Clinical aspects of teratogenicity of drugs. Excerpta Médica. Oxford: Elsevier Publ. Co., 1976, p. 99-270.

NOGUEIRA, T.O.; STENE, T.; KOPPANG, H.S. Long term effects of colchicine on dentinogenesis of rat incisors. Scand. J. Dent. Res. 88:15-21, 1980.

NOGUEIRA, T.O.; STENE, T.; KOPPANG, H.S. Colchicine effects on rat incisor odontoblasts and dentinogenesis. Scad. J. Dent. Res. 89:48-58, 1981.

NORDLINDER, H. Malformations in newborn rats treated with a single dose of cyclophosphamide. Acta. Soc. Med. Upsal. 26:87-90, 1971.
SHAH, R.M.; MACKAY, R.A. Teratological evaluation of 5-fluorouracil and 2-bromo-2-deoxyuridine on hamster fetuses. J. Embryol. Exp. Morph. 43:47-54, 1978.

STADLER, H.E.; KNOWLES, J. Fluorouracil in pregnancy: Effects on the neonate. JAMA. 217:214215, 1971.

STEPHENS, J.D.; GOLBUS, M.S.; MILLER, T.R. Multiple congenital anomalies in a fetus exposed to 5-fluorouracil during the first trimester. Amer. J. Obstet, Gynecol. 137:747-749, 1980.

THOMPSON, D.J.; MOLELLO, J.A.; STREBING, R.J. Teratogenicity of adriamycin and daunomycin in the rat and rabbit. Teratology. 17:151-158, 1976.

TOBIAS, J.S.; BLOOM, H.J.G. Doxorrubicin in pregnancy. The Lancet. 5:776, 1980.

VAHLSING, H.L. Dental abnormalities in rats after a single large dose of cyclophosphamide. Cancer Res. 35:2199-202, 1975.

VAHLSING, H.L. Cyclophosphamide-induced abnormalities in the rat incisors of the rat. J. Dent. Res. 56:809-16, 1977.

WILSON, J.G. Use of rhesus monkeys in teratological studies. Fed. Proc. 30:104-109, 1971. 